Vija Kalniņa, $M g$. iur.

Latvijas Universitātes Juridiskā fakultāte, Latvija

\title{
SUBJEKTI, KURI VAR ATSAUKTIES UZ PAKALPOJUMU SNIEGŠANAS BRĪVĪBU LĪDZDALĪBAS EKONOMIKĀ
}

\section{SUBJECTS WHICH MAY RELY ON FREEDOM TO PROVIDE SERVICES IN SHARING ECONOMY}

\begin{abstract}
Summary
The personal sphere of application determines which subjects can rely on the freedom to provide services. The sharing economy services are being provided differently than traditional services, involving sharing economy platforms and nonprofessional service providers. The analysis of the rulings of the Court of Justice of the European Union gives ground to conclusions that sharing economy service receivers and service providers (platforms, professional and non-professional service providers) should be protected by the freedom to provide services.
\end{abstract}

Atslēgvārdi: pakalpojumu sniegšanas brīvība, līdzdalïbas ekonomika, pakalpojumi, pakalpojumu sniedzēji, pakalpojumu saṇēmēji, Eiropas Savienība

Keywords: free movement of services, sharing economy, services, service providers, service receivers, the European Union

\section{Ievads}

Līguma par Eiropas Savienības darbību (turpmāk - LESD) 57. pantā ir nostiprināta pakalpojumu sniegšanas brīvība (viena no četrām Eiropas Savienības (turpmāk ES) ekonomiskajām pamatbrīvībām), kas paredz ES dalībvalstīm pienākumu atturēties no šķērṣ̌̌u likšanas pakalpojumu sniegšanai. Proti, dalïbvalstis nedrīkst ierobežot pārrobežu pakalpojumu sniegšanu un san,emšanu. ${ }^{1}$ Pakalpojumu sniegšanas brīvība no pārmērīgiem dalībvalstu ierobežojumiem aizsargā gan pakalpojumu sniedzējus, gan arī pakalpojumu sañēmējus. ${ }^{2}$

Pēdējo 10 gadu laikā ir attīstījies globāls ekonomikas fenomens - līdzdalības ekonomika, ${ }^{3}$ kas latviešu valodā tiek saukta arī par sadarbības vai sadarbīgo ekonomiku (no anglu valodas sharing economy, collaborative economy, peer-to-peer economy, gig economy). Pastāv dažādi viedokḷi par to, kāda veida pakalpojumi veido līdzdalỉbas

Craig P., Búrca G. EU Law. Text, Cases and Materials. Fourth Edition. New York: Oxford University Press, 2008, p. 813.

2 Barnard C. The Substantantive Law of the EU. Fifth edition. New York: Oxford University Press, 2016, p. 293.

3 Hou L. Destructive Sharing Economy: A passage from status to contract. Beijing: Elsevier, 2018, p. 1. 
ekonomiku, taču neatkarīgi no izpratnes to parasti raksturo trīs galvenās pazìmes: interneta platformas, personas, kas iesaistās pakalpojumu sniegšanā, un brīvo resursu, neatkarīgi no to veida, efektīva izmantošana. Atškirīibā no tradicionālā pakalpojumu nodrošināšanas model̦a, kur iesaistīts pakalpojumu sniedzējs un pakalpojumu saṇēmējs, līdzdalības ekonomikas pakalpojumu sniegšanā ir iesaistīti divi subjekti - persona, kas faktiski sniedz pakalpojumu (izpilda attiecīgā pakalpojuma sniegšanai raksturīgās darbības) un līdzdalïbas ekonomikas platformas turētājs, kas nodrošina interneta platformu vai aplikāciju, ar kuras palīdzību tiek organizēta pakalpojumu sniegšana (kas atbilst starpniecībai), ${ }^{4}$ vai pat iesaistās paša pakalpojuma sniegšanā, nosakot cenu, kvalitātes prasības u. c. svarīgus pakalpojuma aspektus. ${ }^{5}$ Papildus tam līdzdalības ekonomikai ir raksturīgi, ka pakalpojumu sniegšanā iesaistās personas, kuras nav profesionāles attiecīgo pakalpojumu sniegšanā, ${ }^{6}$ piemēram, pārvadājumus nodrošina personas, kas nav licencēti taksometru vadìtāji, vai izmitināšanas pakalpojumus nodrošina personas, kas nav saistītas ar viesnīcu biznesu. Turklāt šīs personas pakalpojumu sniegšanai izmanto sev dažādus piederošus resursus, kas tām attiecīgajā brīdī pašām nav nepieciešami, piemēram, dzīvojamās telpas, automašīnas, iekārtas un instrumentus, savu laiku un prasmes. ${ }^{7}$ Pazīstamākie līdzdalības ekonomikas model̦u piemēri ir Uber, Latvijā - Bolt, Airbnb, Taskrabbit, BlaBlaCar.

Lìdzdalības ekonomikas pakalpojumu sniegšana nav tikai lokāla, proti, nenotiek tikai vienā valstī, bet bieži vien, pateicoties tehnolog̣iju iespējām, tai raksturīgs pārrobežu elements ${ }^{8}$ - būs konstatējama pakalpojuma sniedzēja, sañēmēja vai paša pakalpojuma pārvietošanās pāri robežām. ${ }^{9}$ Pārrobežu elements ir viens no priekšnoteikumiem, lai uz pakalpojumu varētu attiecināt pakalpojumu sniegšanas brīvību. ${ }^{10}$ Taču līdzās tam ir vēl arī vairāki citi apstākḷi, kas ir jākonstatē un jānovērtē, lai uz pakalpojumu varētu attiecināt pakalpojumu sniegšanas brīvību. ${ }^{11}$ Viens no šādiem noskaidrojamiem apstākliem ir personas, kas ir tiesīgas atsaukties uz pakalpojumu sniegšanas brīvību un tādējādi aizsargāt sevi pret dalībvalstu noteiktiem ierobežojumiem pakalpojumu sniegšanai. ${ }^{12}$ Šā raksta mērḳis ir noteikt personas, kuras ir tiesīgas atsaukties uz pakalpojumu

4 Petropoulos G. An economic review of the collaborative economy. Policy Contribution, Issue No 5, 2017, p. 3.

5 Hatzopoulos V., Roma S. Caring for Sharing? The collaborative economy under EU law. Common Market Law Review, Vol. 54, No. 1, 01.02.2017., p. 95; Komisijas pazinojums Eiropas Parlamentam, Padomei, Eiropas Ekonomikas un sociālo lietu komitejai un Reǵionu komitejai. Eiropas sadarbīgās ekonomikas programma. $\operatorname{COM}(2016) 356$ final, 6.lpp.

6 De Costa M. F. Sharing Economy: From B2C to P2P and Back. In: Redihna M. R., Guimarães M. R., Fernandes F. L. (eds.). The Sharing Economy. Legal Problems of a Permutations and Combinations Society. Newcastle upon Tyne: Cambridge Scholars Publishing, 2019, p. 16.

Petropoulos G., pp. 2-3.

8 Mota H. The Cross-Border Contracts on Sharing Economy. In: Redihna M. R. et al., p. 449.

9 Pārrobežu elementa pastāvēšana attiecībā uz līdzdalības ekonomikas platformām ir konstatēta lietā Eiropas Savienības Tiesas 2017. gada 20. decembra spriedums lietā C-434/15 Asociación Profesional Elite Taxi, 15. punkts.

10 Barnard C., pp. 292-295.

11 Sk., piemēram, Schmitz T. Kāzusi un mācību materiāli Eiropas Savienības tiesībās. Rīga: Tiesu namu aǵentūra, 2010, 226.-232. lpp.

12 Ibid. 
sniegšanas brīvỉbu līdzdalības ekonomikā, ievērojot atškłirības līdzdalības ekonomikas pakalpojumu sniegšanā.

Pakalpojumu sniegšanas brīiības jēdziens ir autonoms ES tiesỉbu jēdziens, kura saturs nosakāms, interpretējot ES dibināšanas līgumus, direktīvas un Eiropas Savienības Tiesas (turpmāk - EST) judikatūras atziņas. ${ }^{13}$ Tieši tāpat arī citi jēdzieni, kas ir saistīti ar pakalpojumu sniegšanas brīvỉbu, tās piemērošanas sfēru un saturu, ir vērtējami autonomi, izmantojot šo pieeju, neatkarīgi no to nozīmes citās tiesību nozarēs. Tāpēc rakstā subjekti, ko līdzdalības ekonomikā aizsargā pakalpojumu sniegšanas brīvỉba, tiks noteikti, analizējot ES tiesību aktos un EST judikatūras atziņās noteikto. Vispirms vērtētas līdzdalības ekonomikas pakalpojumu saṇēmēju tiesības atsaukties uz pakalpojumu sniegšanas brīvỉbu, bet pēc tam - līdzdalïbas ekonomikas pakalpojumu sniedzēju tiesības, dalot tos divās grupās - līdzdalības ekonomikas platformu turētāji un vispārējā pakalpojuma sniedzēji.

\section{Pakalpojumu saṇēmēji līdzdalības ekonomikā}

Lai arī LESD 56.-57. panta formulējums var radīt priekšstatu, ka pakalpojumu sniegšanas brīviba aizsargā tikai pakalpojumu sniedzējus un viṇu tiesỉbas sniegt pakalpojumus, ievērojot apstākli, ka pakalpojumu sniegšanā ir nozīme arī tam, ka pakalpojumu saņēmēji var doties uz citu dalïbvalsti saņemt pakalpojumus, arī pakalpojumu sañēmējus aizsargā pakalpojumu sniegšanas briviiba. ${ }^{14}$ Tas, ka pakalpojumu sniegšanas brīība aizsargā arī pakalpojumu saṇēmējus, ir ticis apstiprināts gan ES normatīvajos aktos, ${ }^{15}$ gan arī EST judikatūrā, uzsverot pakalpojumu saṇēmēju tiesību aizsardzības nozīmību pakalpojumu tirgus liberalizācijā. Pakalpojumu saṇēmēju tiesību aizsardzības nepieciešamība pakalpojumu sniegšanas brīvības funkcionēšanas nodrošināšanai pirmo reizi tika atzīta lietā Luisi un Carbone ${ }^{16}$ un vēlāk apstiprināta arī vairākās citās lietās. ${ }^{17}$

Arī līdzdalïbas ekonomikas pakalpojumu kontekstā pakalpojumu saņēmēju tiesību brīvi piekḷūt līdzdalības ekonomikas pakalpojumiem nodrošināšana ir nozīmīga. Liela daļa līdzdalības ekonomikas pakalpojumu ir orientēti uz tūristu apkalpošanu, ${ }^{18}$ tāpēc nepārprotami būs konstatējami gadījumi, kad pakalpojuma sañēmējs dosies

13 Van Rossem J. W. The Authonomy of EU Law: More is Less? Pieejams: http://www.springer.com/ cda/content/document/cda_downloaddocument/9789067049023-c2.pdf?SGWID=0-0-451367037-p174605404 [aplūkots 04.07.2019.].

14 Barnard C., p. 293.

15 Sk. Padomes 1973. gada 21. maija Direktīvas 73/148/EEK par dalībvalstu pilsoṇu pārvietošanās un dzīvesvietas Kopienā ierobežojumu atcelšanu saistībā ar uzṇēmējdarbību un pakalpojumu sniegšanu 1. panta 1. punkta b) apakšpunktu.

16 Eiropas Kopienu tiesas 1984. gada 31. janvāra spriedums apvienotajās lietās 286/82 un 26/83 Luisi un Carbone/Ministero dello Tesoro, 10. punkts.

17 Sk., piemēram, Eiropas Kopienu tiesas 2001. gada 29. novembra spriedumu lietā C-17/00 De Coster, 33. punktu, Eiropas Kopienu tiesas 2001. gada 12. jūlija spriedumu lietā C-157/99 Smits un Peerbooms, 53. punktu.

18 Dredge D., Gyimóthy S. (eds.). Collaborative Economy and Tourism. Perspectives, Politics, Policies and Prospects. Cham: Springer International Publishing, 2017, p. 2. 
uz citu dalībvalsti saņemt, piemēram, izmitināšanas vai transporta pakalpojumus. ${ }^{19}$ Personas, kas kā pakalpojumu saṇēmēji līdzdalības ekonomikā ir tiesīgi atsaukties uz pakalpojumu sniegšanas brīvību, līdzīgi kā tas ir arī ar jebkuru citu pakalpojumu, ir jebkurš pakalpojumu saṇēmējs neatkarīgi no tā, vai tā ir fiziskā persona (kā patērētājs vai kā pašnodarbinātais) vai juridiskā persona. ${ }^{20}$

Jānorāda gan, ka līdz šim nav identificēti tādi dalībvalstu noteikti ierobežojumi līdzdalïbas ekonomikai, kas būtu vērsti tieši uz pakalpojumu saṇēmēju tiesību ierobežošanu saņemt līdzdalības ekonomikas pakalpojumus citā dalībvalstī vai no citas dalībvalsts pakalpojumu sniedzēja. Tomēr, pēc autores domām, līdzšinējā EST judikatūra par citu pakalpojumu saņēmējiem ir pietiekami pārliecinoša un dod pamatu uzskatīt, ka arī līdzdalības ekonomikas pakalpojumu saņēmēji var paļauties uz pakalpojumu sniegšanas brīvību.

\section{Pakalpojumu sniedzēji lìdzdalỉbas ekonomikā}

Kā norādìts iepriekš, līdzdalības ekonomikā pakalpojumu sniegšanas modelis atšķiras no tradicionālā pakalpojumu sniegšanas model̦a, jo pakalpojumu sniegšanā ir iesaistīti divi subjekti - līdzdalības ekonomikas platformas turētājs un pakalpojuma sniedzējs (faktiskais pakalpojuma nodrošinātājs). Turklāt līdzdalības ekonomikā iesaistās arī personas, kas nav attiecīgās nozares profesionāḷi un speciālisti. Abi minētie apstākḷi sarežğì pakalpojumu sniedzēju noteikšanu līdzdalības ekonomikā.

No LESD 56. un 57. panta formulējuma izriet, ka pakalpojumu sniegšanas brīvība aizsargā dalībvalstu pilsoṇus, kas veic uzn̦ēmējdarbību kādā dalībvalstī, bet sniedz pakalpojumus citas dalïbvalsts personai. Prasība pēc tā, lai persona ne tikai sniegtu pakalpojumus, bet arī nodarbotos ar uzņēmējdarbību, ir iekl̦auta arī Eiropas Parlamenta un Padomes 2006. gada 12. decembra Direktīvā 2006/123/EK par pakalpojumiem iekšèjā tirgū (Pakalpojumu direktīva). Pēc minētajām pazīmēm uz pakalpojumu sniegšanas brīvību varētu atsaukties tikai līdzdalības ekonomikas platformu turētāji un profesionālie pakalpojumu sniedzēji, bet ne personas, kas nav profesionāli un kas pakalpojumu sniegšanā iesaistās neregulāri. Tomēr EST judikatūras atziṇās ir norādes uz to, ka arī šādas personas varētu pretendēt uz pakalpojumu sniegšanas brīvības aizsardzību.

\subsection{Lidzdalïbas ekonomikas platformu turētāji}

Jautājumu par līdzdalības ekonomikas platformu turētājiem kā pakalpojumu sniedzējiem EST ir vērtējusi divās Uber lietās. Drīzumā gaidāms spriedums AIRBNB Ireland lietā, kur generāladvokāts Macejs Špunars 2019. gada 30. aprīlī jau ir izteicis savus secinājumus. Šajās lietās risināts jautājums par to, kā klasificējami līdzdalības

19 Dredge D., Gyimóthy S. (eds.) Collaborative Economy and Tourism. Perspectives, Politics, Policies and Prospects. Cham: Springer International Publishing, 2017, pp. 24-25.

20 Kalniņa V. Pakalpojumu sniegšanas brīvība. No: Shewe C. (zin. red.). Eiropas Savienības tiesības. II daḷa. Materiālās tiesības. Rīga: Tiesu namu agentūra, 2016, 285. lpp. 
ekonomikas pakalpojumi, lai uz tiem varētu attiecināt pakalpojumu sniegšanas brīvību. Lai gan šo lietu centrālais jautājums nav noteikt pakalpojumu sniedzējus, kas līdzdalỉbas ekonomikā var atsaukties uz pakalpojumu sniegšanas brīvỉbu, EST spriedumos paustās atzinas apstiprina, ka līdzdalības ekonomikas platformu turētājiem šādas tiesïbas var piemist.

Pēc EST secinājumiem, Elite Taxi lietā līdzdalïbas ekonomikas pakalpojumi ir kompleksi pakalpojumi (pakalpojumi, ko veido vairāki elementi un posmi) un to sniegšanā ir iesaistìts ne tikai vispārējā vai gala pakalpojuma (angḷu val. overall service) sniedzējs, kas faktiski izpilda attiecīgajam pakalpojumam raksturīgās darbības, bet arī līdzdalības ekonomikas platformas turētājs. ${ }^{21}$ Šãdus secinājumus EST izdarīja, balstoties uz informāciju par Uber platformas būtisku iesaisti neprofesionālo transporta vadītāju sniegto pakalpojumu noteikšanā un nodrošināšanā. ${ }^{22}$ Ievērojot to, ka gan platformas turētājs ir atzìts par līdzdalïbas ekonomikas pakalpojuma sniedzēju, platformas turētājam ir tiesības paļauties uz pakalpojumu sniegšanas brīvỉbu. Vienīgi Uber uz pakalpojumu sniegšanas brīvibu nevarēja paļauties, jo transporta pakalpojumi saskañā ar LESD 58. panta 1. punktu ir izslēgti no pakalpojumu sniegšanas brīiibas aizsardzības. ${ }^{23}$

Minētie secinājumi tika apstiprināti arī lietā Uber France, ${ }^{24}$ taču interesants pagrieziens varētu būt EST spriedums lietā AIRBNB Ireland, kur EST jāvērtē citas līdzdalības ekonomikas platformas darbība. Generāladvokāts M. Špunars šajā lietā atkāpjas no saviem secinājumiem Uber lietās, ${ }^{25}$ kuriem spriedumā sekoja arī EST, nekonstatējot Airbnb būtisku iesaisti izmitināšanas pakalpojumu sniegšanā. ${ }^{26}$ G̣enerāladvokāta secinājumi rada daudz jautājumu, jo Airbnb un Uber iesaiste vispārējo pakalpojumu sniegšanā ir ḷoti līdzīga, un liek secināt, ka pat mazākā atkāpe no Uber veiktajām darbībām dos pamatu konstatēt starpniecības pakalpojumus, nevis būtisku iesaisti vispārējā jeb gala pakalpojumu sniegšanā. Taču ar šādu pieeju līdzdalïbas ekonomikas pakalpojumi netiktu skatīti kopā, bet gan kā divi atsevišķi pakalpojumi - vispārējais pakalpojums un starpniecības platformas pakalpojums ar atšksirīgiem subjektiem kā pakalpojumu sniedzējiem.

Vienlaikus tomēr jānorāda, ka apstāklim, vai līdzdalïbas ekonomikas platformas turētājs tiek atzīts par starpniecības pakalpojumu sniedzēju vai pakalpojuma sniedzēju attiecīgajā jomā, nav būtiska ietekme uz to, vai līdzdalïbas ekonomikas platforma varēs paļauties uz pakalpojumu sniegšanas brīvỉbu. Tāda iespēja platformai būs gan vienā, gan otrā gadījumā. Vienīgā atšķirība ir tā, ka gadījumā, ja platformas turētāju atzīst par starpnieku, pēc Eiropas Parlamenta un Padomes 2000. gada 8. jūnija Direktīvas

21 Eiropas Savienības Tiesas 2017. gada 20. decembra spriedums lietā C-434/15 Asociación Profesional Elite Taxi, 40. punkts.

22 Ibid., 38.-39. punkts.

23 Ibid., 44. punkts. Transporta pakalpojumus dalībvalstis ir tiesīgas brīvi ierobežot citu valstu pakalpojumu sniedzējiem, jo šì pakalpojumu sfēra nav liberalizēta.

24 Eiropas Savienības Tiesas 2018. gada 10. aprị̣la spriedums lietā C-320/16 Uber France, 22. punkts.

25 Sk., piemēram, generāladvokāta Maceja Špunara 2017. gada 11. maija secinājumus lietā C-434/15 Asociación Profesional Elite Taxi, 61.-63. punkts.

26 G̦enerāladvokāta Maceja Špunara 2019. gada 30. aprịla secinājumi lietā C-390/18 AIRBNB Ireland, 86.-91. punkts. 
2000/31/EK par dažiem informācijas sabiedrības pakalpojumu tiesiskiem aspektiem, jo īpaši elektronisko tirdzniecību iekšèjā tirgū būs piemērojami papildu aizsardzības pasākumi, dalībvalstij ziņojot Eiropas Komisijai par ierobežojošiem noteikumiem. Savukārt Uber neveiksmīgs apstāklis izrādījās tas, ka transporta pakalpojumi ir izslēgti ārpus pakalpojumu sniegšanas brīvības aizsardzības un Uber sniegto pakalpojumu atzī̌sana par pakalpojumiem transporta jomā izslēdza tos no pakalpojumu sniegšanas brīvibas aizsardzības.

\subsection{Vispārējā pakalpojuma sniedzēji}

Līdzdalības ekonomikas platformu turētāiji, pēc EST judikatūras atzin̄ām, ir subjekti, kas var paļauties uz pakalpojumu sniegšanas brīvības aizsardzību. Tomēr, kā jau konstatēts, lìdzdalïbas ekonomikas pakalpojumu sniegšana ir kompleksa - tajā iesaistìti vairāk nekā viens pakalpojumu sniedzējs - līdzdalïbas ekonomikas platformu un faktisko pakalpojuma sniedzēju. Turklāt līdzdalības ekonomikā vispārējo pakalpojumu bieži sniedz personas, kurām tā ir papildu, nevis galvenā nodarbošanās, tāpēc vinu darbība nekḷūst par pamatnodarbošanos, komercdarbỉbu vai saimniecisko darbỉbu. ${ }^{27}$ Vienlaikus jānorāda, ka ar līdzdalïbas ekonomikas platformu starpniecību pakalpojumus var sniegt un sniedz arī profesionāl,i. ${ }^{28}$

ES pašreizējais regulējums (LESD 56. pants un Pakalpojumu direktīva) par to, kas ir uzskatāmi par pakalpojumu sniedzējiem, balstās uz pien̦ēmumu, ka pakalpojumus sniedz personas, kas ir profesionāḷi, kam pakalpojumu sniegšana ir saimnieciskā nodarbošanās. Vienlaikus EST judikatūrā subjekta, kuram kā pakalpojumu sniedzējam ir tiesības paļauties uz pakalpojumu sniegšanas brīvību, noteikšanai lielāku nozīmi pieškłir nevis personas statusam (vai tā ir reǵistrējusies kā pašnodarbinātais u. tml.), bet gan tam, vai par sniegto pakalpojumu tiek sañemta atlīdzība. Piemēram, lietā Jundt EST uzsvēra, ka izškirošais elements, kura dēḷ darbība ietilpst LESD noteikumu par pakalpojumu sniegšanas brīvību piemērošanas jomā, ir to saimnieciskais raksturs, proti, pakalpojumam jābūt sniegtam par atlīizzību, kā arī nav nozīmes tam, vai pakalpojumu sniedzējs vēlas gūt pelñu. ${ }^{29}$ Tādējādi par pakalpojumu sniedzēju var atzīt gan pensionējušos pasniedzēju, ${ }^{30}$ gan sportistu amatieri. ${ }^{31}$ Minēto iemeslu dēl arī jebkura persona, kas nav nozares profesionālis vai speciālists, bet kurš sniedz pakalpojumus pret atlīdzību, neskatoties uz tās biežumu un, vai tā tiek veikta atkārtoti, varētu tikt uzskatìts par pakalpojuma sniedzēju, kas var paḷauties uz pakalpojumu sniegšanas brīvību. ${ }^{32}$ Lai arī attiecỉbā uz līdzdalības ekonomiku šādi secinājumi EST vēl nav tikuši apstiprināti, pēc autores domām, minētās EST judikatūras atziṇas norāda uz to, ka uz līdzdalības ekonomikas vispārējo pakalpojumu sniedzējiem, kas nav profesionāḷi, pakalpojumu sniegšanas brīviba varētu tikt attiecināta.

27 Hatzopoulos V., Roma S., p. 114.

28 Petropoulos G., p. 8.

29 Eiropas Savienības Tiesas 2007. gada 18. decembra spriedums lietā C-281/06 Jundt, 32. un 33. punkts.

30 Ibid., 34. punkts.

31 Eiropas Kopienu tiesas 2000. gada 11. aprīla spriedums lietā C-191/97 Deliège, 64. punkts.

32 Hatzopoulos V, Roma S., p. 114. 
Neprofesionāḷu iesaistīšanās tirgū nav raksturīga tikai līdzdalības ekonomikai, bet tā notiek arī citās ekonomiskās aktivitātēs, kas pilnīgi vai daḷēji tiek īstenotas digitālajā vidē, piemēram, tirdzniecībā vai citu pakalpojumu sniegšanā. Arī šajās nozarēs ir aktuāls jautājums par neprofesionālu tiesisko statusu, tiesībām un pienākumiem. Kā piemērs lietai, kurā EST ir bijis jārisina jautājums par neprofesionāļu tiesisko statusu, ir jāmin lieta Kamenova. Šajā lietā fiziskā persona veica atsevišķu priekšmetu tirdzniecību interneta platformā, un EST bija jāskaidro, vai uz šādu personu, kas nav komersants (persona, kas darbojas nolūkos, kas ir saistīti ar tās komercdarbību, uzṇēmējdarbību, amatniecisko darbību vai profesiju), ${ }^{33}$ ir attiecināms negodīgas komercprakses aizliegums. Šajā lietā EST noteica, ka jāvērtē katrs gadijums atsevišḳi, uzskaitot dažādus apstākḷus, kas varētu ietekmēt to, vai persona ir atzīstama par tirgotāju. ${ }^{34}$ Lai fizisko personu atzìtu par tirgotāju, nepietiks konstatēt tikai pel̦n,nas gūšanas nolūku un vairākus mēgénājumus pārdot dažādas preces. ${ }^{35}$

EST secinājumu lietā Kamenova gaismā neprofesionālo līdzdalības ekonomikas pakalpojumu sniedzēji ne vienmēr veic ekonomisko darbību un nevarētu tikt atzìti par personām, kas veic uzṇēmējdarbību un ir aizsargājami ar pakalpojumu sniegšanas brīvību. Tomēr, pirmkārt, lietā Kamenova lietas apstākḷi bija saistīti ar preču tirdzniecību internetā, nevis pakalpojumu sniegšanu, tāpēc šìs atziñas līdzdalības ekonomikas pakalpojumiem varētu piemērot tikai pēc analogijas. Otrkārt, juridiskajā literatūrā pastāv viedoklis, ka pakalpojuma sniedzēja jēdziens ir plašāks par tirgotāja jēdzienu patērētāju un negodīgas komercprakses kontekstā. ${ }^{36}$

Autoresprāt, atbilde uz jautājumu, vai vispārējā pakalpojuma sniedzējs, kas nav profesionālis, var atsaukties uz pakalpojumu sniegšanas brīvību, nav nepārprotama. Lai arī pakalpojumu sniegšanas brīvības kontekstā līdz šim pakalpojumu sniedzēju jēdziens ir bijis plašs, nevar neievērot to, ka secinājumi par pakalpojumu sniegšanas brīvības attiecināmību uz neprofesionāliem pakalpojumu sniedzējiem var ietekmēt arī šādu pakalpojumu sniedzēju statusu citos jautājumos kā, piemēram, patērētāju tiesību aizsardzība un negodīgas komercprakses novēršana. Šajos citos jautājumos neprofesionālu pielīdzināšana profesionāliem nebūtu samērīga, kā tas ir atzīts arī lietā Kamenova.

\section{Kopsavilkums}

1. Pakalpojumu sniegšanas brīvība līdzdalības ekonomikā aizsargā gan pakalpojumu sniedzējus, gan to sañēmējus.

2. Lai personu atzītu par pakalpojumu sniedzēju pakalpojumu sniegšanas brīvības kontekstā, atbilstoši LESD 56. pantam un Pakalpojumu direktīvai tai ir jānodarbojas ar uzñēmējdarbību. Tādos apstākḷos par pakalpojumu sniedzējiem līdzdalības ekonomikā var atzìt tikai līdzdalības ekonomikas platformu turētājus

\footnotetext{
33 Eiropas Savienības Tiesas 2018. gada 4. oktobra spriedums lietā C-105/17 Kamenova, 32. punkts.

${ }^{34}$ Ibid., 38. punkts.

${ }^{35}$ Ibid., 39. punkts.

${ }^{36}$ Hatzopoulos V, Roma S., p. 114.
} 
un profesionāļus, kas savus pakalpojumus sniedz, izmantojot šīs platformas. Pēc šādas formālas pieejas personas, kas nav profesionāļi pakalpojumu sniedzēji, bet sniedz pakalpojumus, izmantojot līdzdalíbas ekonomikas platformas, nevarētu tikt atzīti par pakalpojumu sniedzējiem, ko aizsargā pakalpojumu sniegšanas brīvība.

3. Pastāv dažādi viedokḷi par to, vai pakalpojumu sniedzēji, kas nav profesionāli, būtu atzīstami par pakalpojumu sniedzējiem pakalpojumu sniegšanas brīvības kontekstā. No vienas puses, EST līdzšinējie secinājumi par pakalpojumu sniedzējiem dod pamatu paļauties, ka arī neprofesionālos pakalpojumu sniedzējus aizsargā pakalpojumu sniegšanas brīvība. No otras puses, attiecībā uz citām ekonomiskajām aktivitātēm tiek ierobežota tiesību un pienākumu (piemēram, patērētāju un negodīgas komercprakses jautājumos), kas attiecas uz profesionāliem, piemērošana personām, kas nav profesionāli. Pakalpojumu sniedzēju, kas nav profesionāḷi, atzīšana par pakalpojumu sniegšanas brīvības subjektiem nedrīkstētu viņiem radìt nesamērīgus un neatbilstošus pienākumus citos tiesību jautājumos.

\section{BIBLIOGRĀFIJA}

\section{Literatūra}

1. Barnard C. The Substantantive Law of the EU. Fifth edition. New York: Oxford University Press, 2016.

2. Craig P., Búrca G. EU Law. Text, Cases and Materials. Fourth Edition. New York: Oxford University Press, 2008.

3. Dredge D., Gyimóthy S. (eds.). Collaborative Economy and Tourism. Perspectives, Politics, Policies and Prospects. Cham: Springer International Publishing, 2017.

4. Goudin P. The Cost of Non-Europe in the Sharing Economy. Economic, Social and Legal Challanges and Opportunities. Brussels: European Added Value Uniti, 2016.

5. Hatzopoulos V., Roma S. Caring for Sharing? The collaborative economy under EU law. Common Market Law Review, Vol. 54. No. 1, 01.02.2017, pp. 81-127.

6. Hou L. Destructive Sharing Economy: A passage from status to contract. Beijing: Elsevier, 2018.

7. Petropoulos G. An economic review of the collaborative economy. Policy Contribution, Issue No 5, 2017.

8. Redihna M. R., Guimarães M. R., Fernandes F. L. (eds.). The Sharing Economy. Legal Problems of a Permutations and Combinations Society. Newcastle upon Tyne: Cambridge Scholars Publishing, 2019.

9. Rossem J. W., van. The Authonomy of EU Law: More is Less? Pieejams: http://www.springer. com/cda/content/document/cda_downloaddocument/9789067049023-c2.pdf?SGWID=00-45-1367037-p174605404 [aplūkots 04.07.2019.].

10. Shewe C. (zin. red.). Eiropas Savienības tiesības. II daļa. Materiālās tiesības. Rīga: Tiesu namu aǵentūra, 2016.

11. Schmitz T. Kāzusi un mācību materiāli Eiropas Savienības tiesībās. Rīga: Tiesu namu aǵentūra, 2010. 


\section{Normativie akti}

12. Padomes 1973. gada 21. maija Direktīvas 73/148/EEK par dalïbvalstu pilsoṇu pārvietošanās un dzīvesvietas Kopienā ierobežojumu atcelšanu saistībā ar uzṇēmējdarbību un pakalpojumu sniegšanu.

13. Eiropas Parlamenta un Padomes 2006. gada 12. decembra Direktīva 2006/123/EK par pakalpojumiem iekšèjā tirgū.

14. Eiropas Parlamenta un Padomes 2000. gada 8. jūnija Direktīvu 2000/31/EK par dažiem informācijas sabiedrības pakalpojumu tiesiskiem aspektiem, jo īpaši elektronisko tirdzniecỉbu iekšêjā tirgū.

\section{Juridiskā prakse}

15. Eiropas Savienības Tiesas 2018. gada 10. aprīla spriedums lietā C-320/16 Uber France.

16. Eiropas Savienības Tiesas 2018. gada 4. oktobra spriedums lietā C-105/17 Kamenova.

17. Eiropas Savienības Tiesas 2017. gada 20. decembra spriedums lietā C-434/15 Asociación Profesional Elite Taxi.

18. Eiropas Savienības Tiesas 2007. gada 18. decembra spriedums lietā C-281/06 Jundt.

19. Eiropas Kopienu tiesas 2001. gada 29. novembra spriedumu lietā C-17/00 De Coster.

20. Eiropas Kopienu tiesas 2001. gada 12. jūlija spriedumu lietā C-157/99 Smits un Peerbooms.

21. Eiropas Kopienu tiesas 2000. gada 11. aprīla spriedums lietā C-191/97 Deliège.

22. Eiropas Kopienu tiesas 1984. gada 31. janvāra spriedums apvienotajās lietās 286/82 un 26/83 Luisi un Carbone/Ministero dello Tesoro.

\section{Citi avoti}

23. Komisijas paziñojums Eiropas Parlamentam, Padomei, Eiropas Ekonomikas un sociālo lietu komitejai un Regiionu komitejai. Eiropas sadarbīgās ekonomikas programma. COM(2016) 356 final.

24. Ģenerāladvokāta Maceja Špunara 2017. gada 11. maija secinājumi lietā C-434/15 Asociación Profesional Elite Taxi.

25. G̦enerāladvokāta Maceja Špunara 2019. gada 30. aprīla secinājumi lietā C-390/18 AIRBNB Ireland. 